UDC 159.9:001.8

\title{
THE INCEPTION OF THE SYSTEMIC APPROACH AT THE INSTITUTE OF PSYCHOLOGY OF THE U.S.S.R. ACADEMY OF SCIENCES IN 1972-1973 ${ }^{1}$
}

\author{
(C) 2021 g. V. I. Belopolsky* , A. L. Zhuravlev**, A. A. Kostrigin*** \\ Institute of Psychology of the Russian Academy of Sciences Federal Publicly \\ Funded Institution of Science (FGBUN) \\ 129366, Moscow, Yaroslavskaya str. 13, bld. 1, Russia \\ * Doctor of Psychology, Principal Researcher of the Laboratory \\ of the History of Psychology and Historical Psychology \\ E-mail:vbelop@mail.ru \\ ** Member of the Russian Academy of Sciences, Chief Scientific Officer of the Institute \\ of Psychology of the Russian Academy of Sciences FGBUN \\ E-mail: alzhuravlev2018@yandex.ru \\ ***Candidate of Psychological Sciences, Research Associate, \\ Laboratory of the History of Psychology and Historical Psychology. \\ E-mail: artdzen@gmail.com
}

Submitted 05.05.2020

\begin{abstract}
The process of inception and conceptualization of systemic approach at the Institute of Psychology of the Academy of Sciences of the U.S.S.R. in 1972-1973 is considered. Archival documents, such as transcripts of meetings of the Institute of Psychology and reports on research activities of the laboratories, are analyzed. The role of scientific discussions on interdisciplinarity and complexity of research in formulating the provisions of the systemic approach is shown. The article provides information on previously unknown preparatory materials and the text of B.F. Lomov's 1973 scientific report, in which he first formulated the principles of systemic approach in psychology.
\end{abstract}

Keywords: history of Soviet psychology, systemic approach, scientific discussion, Institute of Psychology of the U.S.S.R. Academy of Sciences, B.F. Lomov, archival documents.

DOI: $10.31857 / \mathrm{S} 020595920015568-0$

The establishment in 1971-1972 of the Institute of Psychology within the structure of the U.S.S.R. Academy of Sciences was an important milestone in the history of national psychology. Leading scientists of the Soviet Union, both psychologists and representatives of other fields of knowledge, took part in its creation. The role of psychology as a special science, which studies regularities of human emotions and feelings, activity and actions, was recognized at the highest levels of the country's leadership and in the academic environment. The Institute was created, first of all, as a research center, aimed at working out fundamental

\footnotetext{
${ }^{1}$ This article is a translation of: Белопольский В. И., Журавлев А. Л., Костригин А. А. Зарождение системного подхода в Институте психологии АН СССР в 1972-1973 гг. // Psikhologicheskii zhurnal. 2021. V. 42. № 1. P. 36-45. DOI: 10.31857/ S020595920013325-3.
}

questions of psychology and solving theoretical and methodological problems of psychological science. Its other statutory tasks were to coordinate works on general, social, engineering psychology, labor psychology, special applied problems of this science and psychophysiology, as well as to participate in the complex study of problems of philosophy, specific social research, physiology of human higher nervous activity, physiology of human adaptation, theory of control processes that were marginal for psychology (a detailed description of the early history of the Institute of Psychology of the U.S.S.R. Academy of Sciences is contained in our other work [13]).

In order to solve such problems, one definitely needs a certain organizing idea, a principle underlying both the organizational and personnel policy for the staffing of the Institute and the research work of its 
subdivisions. The search for, formulation, and concrete implementation of such a principle began as early as the stage of discussing the program of the future academic center and continued after its creation. Such methodological principle was the systemic approach, whose basic provisions with psychological applications were first conceptualized by B.F. Lomov in his 1973 report [29] and then in an expanded and perfected version in 1975 [27; 28].

In this paper we address the issue of the inception of the systemic approach at the Institute of Psychology of the U.S.S.R. Academy of Sciences in the early years of its activity. The systemic view of the processes occurring in nature, society, and man became popular in the 1960s under the influence of the works by L. von Bertalanffy and N. Wiener. In the U.S.S.R. the systemic methodology in the field of philosophy of science was developed by researchers such as I.V. Blauberg and E.G. Yudin [15], M.S. Kagan [21], V.P. Kuzmin [25], V.N. Sadovsky [34], V.S. Tyukhtin [35], A.I. Uyemov [36], and others. The principles of systemic control in biology are the basis of the theories of N.A. Bernstein [14] and P.K. Anokhin [2]. In psychology, the ideas of consistency, integrity, and integrativity were considered in the works by B.G. Ananyev [1], A.N. Leontiev [26], A.R. Luria [32], K.K. Platonov [33], and others, but the Institute of Psychology of the USSR Academy of Sciences became the very research center where the provisions of the systemic approach were initially laid down in the work program and applied in various fields of psychology. The development of the systemic approach took place in the following ways: 1) in scientific communication and discussions about the complexity and interdisciplinarity of psychological research at various events of the Institute of Psychology; 2) in the formulation of research tasks by the staff of the Institute's laboratories. We will consider these directions using archival materials: transcripts of the first Academic Council of the Institute of Psychology of the U.S.S.R. Academy of Sciences in 1972; reports on research activities of the Institute in 19721973; manuscripts from the research fund of B.F. Lomov. It is noted in the scientific literature that B.F. Lomov proposed the systemic approach only in 1975 [12; $18 ; 19 ; 24]$, but the materials we have discovered reveal new facts about the earlier development of systemic ideas at the Institute of Psychology. It should be emphasized that studying the archives is important not only for understanding local historical and scientific events (formation of scientific directions and schools at the Institute), but also for analyzing the history of domestic psychology in a broad sense, searching for the origins and factors of the systemic approach formation [20;23].

\section{DISCUSSIONS ON THE PROBLEMS OF COMPLEXITY AND INTERDISCIPLINARITY \\ IN PSYCHOLOGY AT THE SESSIONS OF THE ACADEMIC COUNCIL \\ OF THE INSTITUTE OF PSYCHOLOGY \\ OF THE U.S.S.R. ACADEMY OF SCIENCES}

IN 1972

At the very beginning of the Institute's functioning, scientific communication was carried out at seminars, which acquired the status of all-Union seminars. In 1972, seminars Major Problems of Psychology (headed, at first, by V.D. Nebylitsyn, then by B.F. Lomov), Methodological Problems of Social Psychology (headed by Ye.V. Shorokhova), Philosophical Problems of Psychology (headed by L.I. Antsyferova), and Methodological Problems of Psychology and Cybernetics (headed by O.K. Tikhomirov) were organized. In 1973, the Institute held a seminar on Psychology and Technical Progress (supervised by V.F. Rubakhin). Interaction with various researchers was ensured by conferences: SocialPsychological Problems of Ethnic and National Peculiarities of Mental Phenomena (1972) and Motor Components of Vision (1973).

However, special attention should be paid to a special body of the Institute of Psychology - the Academic Council. The issue of the creation of the Academic Council was specifically raised by the Presidium of the U.S.S.R. Academy of Sciences when discussing and approving Decree \# 1079 of December 16, 1971, On the Establishment of the Institute of Psychology of the U.S.S.R. Academy of Sciences [5, sheet 119-120]. In 1972-1973 the first members of the Academic Council were: B.F. Lomov (Chairman), V.D. Nebylitsyn (Deputy Chairman), Ye.V. Shorokhova (Deputy Chairman), R.L. Gasanova (Executive Secretary), P.K. Anokhin, A.I. Berg, A.V. Zaporozhets, V.P. Zinchenko, V.Yu. Krylov, A.N. Leontiev, M.N. Livanov, A.R. Luria, N.S. Mansurov, B.D. Parygin, B.F. Porshnev, V.A. Popov, K.K. Platonov, A.R. Ratinov, A.A. Smirnov, A.G. Spirkin, O.K. Tikhomirov, V.F. Rubakhin, V.I. Sevastyanov, P.K. Isakov, V.S. Rusinov, M.G. Yaroshevsky [6, sheet 29-30; 8, sheet 158]. Without exaggeration we can say that it was an academic team of outstanding composition and representation.

The functions of the Academic Council were, first of all, to solve organizational problems of the Institute of Psychology activity (approval of plans and reports of research work, discussion of publication activity of associates, approval of topics of dissertations, etc.); however, in the early years, at its meetings there were often scientific discussions of particular interest for the history 
of psychology. They did not begin immediately, but there was a need for members of the Academic Council to express their opinions in scientific speeches, and this spirit was picked up by B.F. Lomov. In the fall 1972, he said: "I think that next meetings of the Academic Council should be devoted to the consideration of specific problems developed at the Institute" [8, sheet 157]. The first special report was held in 1973 (A.N. Leontiev), however, scientific problems were also raised at previous sessions when plans of the Institute's research work for 1972-1973 were discussed. These scientific discussions are crucial for understanding the choice of research directions for the Institute, since it was in these discussions that the idea of consistency in psychology, which became decisive not only for the Institute's activity, but also for the entire Soviet psychology, was crystallized.

At the first session of the Academic Council of the Institute of Psychology of the U.S.S.R. Academy of Sciences (June 29, 1972) a rather meaningful discussion took place around the first Scientific Research Plan for 1972. Members of the Council expressed great concern over the proposed directions of psychological research since they should have reflected both a great potential of the Institute and be feasible for its small staff at that time. However, B.F. Lomov also set wide-ranging tasks for the future: "...we face the necessity of systemic research of the modern psychology condition, its development trends, its place in the general system of scientific knowledge due to the increased role of the human factor; on the basis of this research, we have to elaborate a prospective program of psychology development" [Ibid., sheet 6].

P.K. Anokhin suggested to consider this idea as a fundamental principle of the whole activity of the Institute: "...the Institute of Psychology is in a happy position. It is not an institute of physiology, where it is a question of digestion. Here it is the psyche, its peculiarities and possibilities of controlling its peculiarities. This raises no less important a question than the fulfillment of the plan of research work. Complexity. This is the only principle, it seems to me, that should dominate the work of the institute as a whole, and it will ensure success. Now, no direction of psychology study, no direction of mental activity study cannot be independent, because the psyche unites all" [Ibid., sheet 32].

A.R. Luria, in turn, saw this as a model for organizing specific departments and laboratories: "The Institute, in my deep conviction, will benefit greatly when the initial fundamental points of individual areas of work are defined and when the content of the work of one department is used as a method for the work of another department. The problem of personality or the problem of cognitive processes can be addressed from different angles, but the Institute will only benefit if each of these problems is addressed comprehensively. Neuropsychology is not only an applied section, but also a method for solving general problems. For example, the factors that underlie cognitive processes can be singled out; the problem of decision-making would benefit greatly if this problem were approached using the methods of neuropsychology. In framing this plan, the possibility of such integrated departmental work should have been considered. This requires more thorough work, and conceptually important provisions, such as the provision on the role of activity structure in the study of psychological processes, should have been highlighted" [Ibid., sheet 28-29].

Such a construction of the Institute's research work seemed to be cardinally new for psychological science: "...the idea was that this Institute of Psychology should be built on an original concept and not tag along behind thousands of other institutes of psychology" (P.K. Anokhin) [Ibid., sheet 34]. In 1972, the idea of psychology's "integration", comprehensiveness sounded rather confidently and promisingly, also among representatives of related disciplines.

At another meeting of the Academic Council in October 1972, the Institute's work plan for 1973-1975 was discussed [7; 8]. B.F. Lomov set a goal to carry out a special study of theoretical and methodological problems of psychology and to elaborate a development program of psychological science as a whole (this task was pointed out specifically in the correspondence of the U.S.S.R. Academy of Sciences Presidium and the CPSU Central Committee in August-September 1971 [4]) and in Decree \# 1079 of the U.S.S.R. Academy of Sciences Presidium of December, 16, 1971 [5]). B.F. Lomov says: "What is meant here is work in the field of analysis of psychology and its place, role, and functions in the system of modern scientific knowledge. Then there is the study of the main trends in the development of world scientific psychology. [...]It is then planned to work out methodological problems of psychology. We mean to organize, in different departments, the development of interfacing problems and the elucidation of the prospects for joint developments. A cycle of studies is being prepared, aimed at elucidating relations, interrelation of psychology with other sciences: psychology and biology, psychology and sociology, psychology and philosophy, psychology and technology, psychology and space exploration" [8, sheet 95].

B.F. Lomov outlines the interdisciplinary links between psychology and other sciences; he also discusses the elements of a systemic study of the psyche. During the discussion of these issues, A.A. Smirnov also points to the need to study the relationship between psychology and pedagogy, psychology and medicine, psychology and cybernetics [Ibid., sheet 105]. O.K. Tikhomirov also speaks about the latter: "Both in world psychology and in Russian psychology, sometimes psychological laws are substituted by cybernetic ones" [Ibid., sheet 117]. 
Finally, Ye.V. Shorokhova concludes: "In our subsequent work to improve our plan, we must move to another level and highlight several difficult problems that would form the core of the work of the entire institute and determine the image of our institute as a theoretical institution of the Academy of Sciences" [Ibid., sheet 135.]

The members of the Academic Council expressed their proposals for specific interdisciplinary problems and research. For example, A.V. Zaporozhets noted that it is necessary to give the research conducted at the Institute of Psychology "a more complex physiological-psychological character and to connect these studies more closely than has been the case up to now. For example, questions of foresight, anticipation, prediction in the sense of foreknowledge. Apparently, there is a very large variety of forms of these phenomena, and it is necessary to describe them simultaneously in psychological and physiological terms" [Ibid., sheet 103]. Joining this idea, O.K. Tikhomirov sees a fundamental connection between psychological and physiological processes: "...if processes evolve, it is connected with general psychology, and specific connections with neuropsychological processes must be established" [Ibid., sheet 117-118].

Many participants in the discussion talked about promising problems at the junction of psychological disciplines. A.A. Smirnov suggests introducing the problem of cognitive processes into engineering psychology, namely, psychology of sensory systems and visual perception in engineering activity and engineering conditions [Ibid., sheet 108]. A.N. Leontiev notes the necessity of combining the psychology of personality and social psychology as part of the issue of personality-collective relations [Ibid., sheet 110]. B.F. Porshnev considers the possibility of studying macrogroups as an interdisciplinary problem and substantiates the use of experimental methods and modeling techniques for this purpose [Ibid., sheet 115]. Regarding applied psychology, P.K. Isakov considers the research topics of the laboratory of special applied problems and suggests combining the study of work capacity and the study of spatial orientation within a single study of psychological aspects of work capacity under various spatial orientation conditions [Ibid., sheet 131-132].

P.K. Anokhin shows the interdisciplinarity of psychological research on the example of the problem of decision-making. In the plan of the Institute of Psychology for 1973-1975 this direction was included in the list of research tasks of the Laboratory of Labor Automation Problems (topic leader: O.K. Tikhomirov, executors: E.D. Telegina, V.A. Terekhov), the Laboratory of Mathematical Models of Behavior (topic leader: V. Yu. Krylov, executors: G. Ye. Zhuravlev and the Institute of Cybernetics of the Georgian SSR), and the Laboratory of Neurophysiology (V.B. Shvyrkov, supervisor: P.K. Anokhin, executors: D.G. Shevchenko and Yu.I. Alexandrov), the Laboratory of Differential Psychophysiology (supervisor: V.D. Nebylitsyn, executor: V.M. Rusalov) and the Laboratory of Philosophical Problems of Psychology in the Framework of Motivation Analysis (supervisor: Ye.V. Shorokhova) [9, sheet $10,12]$. Decision-making is a complex problem that organizes a functional system. P.K. Anokhin notes: “...decision making - it goes on everywhere, with us neurophysiologists, with theoretical psychologists, it goes on in practitioners as well. Decision-making is a universal property of human thinking. Without decision-making, there are no consequences of the rational order. Intelligence, motivation - motivation is necessarily present. This is the basis for us all to build on this common pivot, which is necessarily part of the architecture of the psyche. There is no architecture of the psyche without motivational processes" [8, sheet 121].

Concluding the discussion on the research plans of the laboratories, B.F. Lomov notes that many fundamental problems of psychology (the problem of activity, the problem of anticipation and decision-making, the problem of the ratio of biological and social in the human psyche) should become central to scientific research in the Institute of Psychology [7, sheet 37; 8, sheet 149]. These are "... key problems that require comprehensive development and integrate all the units of the institute". [7, sheet 5].

Thus, the scientific discussions held on the problems of multi-method researches in psychology, as well as the integration of studies of the various fields of psychology show the demand for and relevance of the emergence of systemic ideas. In our opinion, such a lively and timely discussion of these theoretical and methodological issues as illustrated by specific research subjects contributed to the practical implementation of the principles of comprehensiveness and consistency in the works of the Institute of Psychology, which was reflected in the reports on research activities for 1972-1973.

It is also important to mention the meeting of the Institute's Academic Council on March 7, 1973, which discussed A.N. Leontiev's articles on methodological problems of psychology published in the journal Voprosy Filosofii [Problems of philosophy]. In his introductory speech A.N. Leontiev gave his theses for the necessity of a systemic approach in psychology: "It seems to me that all science does not deal with things, and sciences differ from each other not by differences in subject matter $<\ldots>$. Returning to the old truths: it is not about things, nor about aspects or points of view $\langle\ldots\rangle$, but about what philosophers call the form of motion. Thus, the motion of matter, behind which, according to Engels, there is nothing, is always a motion that occurs by force, a motion in created forms. Consequently, what is needed is neither structural 
nor structural-systemic analysis, but rather a systems analysis in the Marxist dialectical sense of the word, that $i s$, a research that should be aimed at studying the transformation of the form of motion" [11, sheet 14].

\section{DEVELOPMENT OF A SYSTEMIC APPROACH IN THE FRAMEWORK OF RESEARCH ACTIVITIES OF THE INSTITUTE OF PSYCHOLOGY STAFF OF THE U.S.S.R. ACADEMY OF SCIENCES IN 1972-1973}

The results of the discussion of theoretical and methodological problems of psychology appeared already in the first report of the Institute of Psychology on research activities in 1972. Based on the dialectical-materialistic methodology, all fundamental questions of psychology "...should be considered in their interconnection and interdependence. This is revealed by the reflectiveregulatory theory of the psyche, according to which the psyche is the reflective function of the brain, which regulates the behavior of the individual" [7, sheet 8].

At the same time, the staff of the Institute approached the idea of systematicity through studies of specific problems of psychology. Thus, L.I. Antsyferova spoke of personality as a system even before she started working at the Institute of Psychology [3]. In the early 1970s, Ye.V. Shorokhova offered a structural study of personality and its components, she revealed "...the characteristics of Marxist positions in the question of the essence of a person, which constitute the basis for understanding personality in psychology, examined the categorical apparatus of psychological study of personality, correlated the concept of a person, an individual and a personality, $<\ldots>$ considered the possibility of a structural approach to personality" [7, sheet 45$]$.

K.K. Platonov developed a system-structural analysis of psychological phenomena, in which integrity, elements, levels and connections within the system are defined, as well as the concept of a dynamic functional structure of personality, which includes substructures of orientation, experience, forms of reflection (individual features of mental processes) and biological features [33].

Under the guidance of B.F. Lomov, the functions and mechanisms of the oculomotor system in connection with the processes of visual perception and recognition were studied in the laboratory of perceptual processes. The concept of the visual system as a tracking device was put forward, which gives the process of visual perception the character of a functional system [7, sheet 10]. The problem of mathematical modeling of mental processes and activities was considered by the staff of the laboratory of mathematical models of human behavior (work under the direction of V. Yu. Krylov). They developed a computer program implementing a self-organizing system with a two-level structure of perceptual and executive spheres [Ibid., sheet 49]. The team of the laboratory of neurophysiological foundations of learning under the leadership of V.B. Shvyrkov and under the active scientific supervision of P.K. Anokhin studied the role of neural activity in the functional system of the behavioral act using decision-making processes as an example [Ibid., sheet 53].

All of this demonstrates a general attitude toward conducting systemic research at the Institute of Psychology, but the systemic approach did not take shape conceptually until the following year.

In 1973, the term "systemic approach" was used in an official document, that is the second report on research work of the Institute of Psychology. This approach stemmed from the need for a comprehensive study of man, in which "... psychology is now called upon to act as the main link" [10, sheet 4]. «The problem of human has already been defined in science as integrated. Human is studied both as a product of biological evolution, and as a subject of the historical process, and as the main element of the productive forces of society, and as a carrier of production relations. Human is included in many systems of reality, and his life proceeds as a multisystem process. Psychology in its specific approach to the study of human as a subject of labor, cognition, and communication is at the "intersection" of many sciences and is designed to synthesize the data accumulated on human in the social, natural, technical sciences» [Ibid., sheet 5]. This position leads to the emergence of systemacity in psychology: «...now conditions are ripe for the actual and consistent implementation of the systemic approach (emphasis in the original) in psychology. The most important task in this respect is to systematize the data accumulated in different fields of psychological science in order to reveal internal connections between them and to develop transitional concepts, or "conceptual bridges" between different fields" [Ibid., sheet 5-6].

And here for the first time the provisions of the systemic approach for psychology are formulated [Ibid., sheet 6]:

- mental phenomena cannot be considered in any one system of coordinates as mental phenomena are multidimensional;

- the system of mental phenomena is multidimensional; the condition of revealing connections between different levels in each specific case is the determination of a systemically important factor; 
- when describing a person's mental properties, it is necessary to take into account the polysystemic nature of his or her existence;

- one of the basic principles of psychological research is the principle of development, which implies the mandatory study of mental phenomena in dynamics.

Thus, systemicity is achieved by recognizing the psyche as a "polysystemic, multilevel, multidimensional object in constant development" [Ibid., sheet 6].

One of the first problems that began to be studied at the Institute of Psychology from the position of the systemic approach was the problem of decision-making (under the guidance of P.K. Anokhin and V.F. Rubakhin). The system of decision-making includes the following aspects: logico-psychological, associated with the dissection and reformulation of tasks into subtasks; neurophysiological, associated with the implementation of a system of neurophysiological mechanisms; operational, associated with the choice and use of a system of operations for informational preparation of decisions, as well as with the construction and testing of hypotheses within a task; functional-dynamic, connected with the realization of a complex of internal psychological mechanisms (logical, heuristic-seeking, probabilistic etc.); personal, associated with the influence of motivationattitudinal and emotional-volitional personality spheres on the course of information processes; "formalized", associated with the quantitative score of information processing and decision-making and the construction of formal models of the procedures in question. "...such a complex human activity, which is the decision-making procedure, can be understood only in case of application of the integrated and systemic approaches in research of this phenomenon, when comparing the results of the analysis of the decision-making process from the standpoint of psychology, cybernetics, physiology, mathematics, etc." [Ibid., sheet 9-10].

Ye.V. Shorokhova denotes her approach to the study and analysis of mental phenomena of personality as a system-structural one: personality is understood not as a set of individual mental processes, properties, states, but as a certain holistic formation that includes separate elements united by certain links [Ibid., sheet 60;37, p. 30]. Within the framework of the problems of labor psychology and engineering psychology, the development of the systemic approach, the selection of "functional-target criteria" for the classification of directions and problems in this field and the conduct of "systemstructural research" were also carried out $[10$, sheet 63-64].

The team of the laboratory of neurophysiological foundations of learning headed by V.B. Shvyrkov was engaged in "... a systems analysis of brain functions as the neurophysiological basis of complex forms of behavior" [Ibid., sheet 24] on the basis of P.K. Anokhin's theory of functional systems. In studies the task was to reveal mechanisms of organization of the behavioral reaction, in particular the role of the process of anticipation in the formation of a separate behavioral act and in behavior consisting of sequentially committed actions. The "different systemic importance" of the same groups of neurons in different phases of the evoked potential ("systemic process") was shown [Ibid., sheet 25]. The laboratory of differential psychophysiology led by V.M. Rusalov developed methodological principles for analyzing the basic properties of the central nervous system based on a systemic (functional-system) approach, in which the particular characteristics of sensory processes can be used as indicators of general properties of the nervous system.

\section{CONCLUSION}

The found archival materials relating to the first years of the activity of the Institute of Psychology of the U.S.S.R. Academy of Sciences make a significant contribution to understanding the formation of psychology in the 1970s, reveal new historical and psychological facts and provide details of scientific research, scientific-organizational and scientific communication processes in science.

The analysis shows that one of the centers of the systemic approach development in the early 1970s was the Institute of Psychology, which attracted many prominent psychologists of the time. It should be noted that, in addition to the research itself, an important factor in the formation of the systemic approach was the scientific discussions that took place at the meetings of the Academic Council of the Institute, i.e. scientific communication guided the theoretical and methodological thought $[22 ; 38]$.

In 1973, B.F. Lomov read a planar report at the 2nd Prague conference The Psychology of Human Learning and Problem Solving [29]. The topic of his report was On the Systemic Approach in Psychology. In this report, for the first time, he publicly formulated the main guidelines and principles of the systemic approach and set a high standard for research conducted at the Institute of Psychology that he led. Apparently, this speech should be considered the birth date of the new scientific school headed by B.F. Lomov.

Thus, systemic ideas, which were still being formed conceptually, began to penetrate into many fields of psychology and into the methodology of research of various psychological problems being solved by the staff of 
the Institute of Psychology of the USSR Academy of Sciences. The principles of systemicity, formulated by B.F. Lomov and other staff members of the Institute of Psychology expanded the research field of psychology, allowed to significantly advance the understanding of many mental phenomena (processes, states, and properties) and to discover new phenomena, which are at the junction of both individual psychological directions and different sciences $[12 ; 17 ; 30 ; 31]$.

\section{ACKNOWLEDGEMENTS}

We express our sincere gratitude to Alexander Rabotkevich, Director of the Archive of the Russian Academy of Sciences, and Mikhail Kiselev, Head of the Records Management and Preservation Department of the Russian Academy of Sciences, for their invaluable help in finding and providing access to the archive materials related to the history of the Institute of Psychology of the Russian Academy of Sciences.

\section{REFERENCES}

1. Ananyev B.G., Chelovek kak predmet poznaniya [Man as a subject of knowledge]. Leningrad University Publishing House, Leningrad, 1968.

2. Anokhin P.K., Sistemniy analiz integrativnoy deyatel'nosti neyrona [Systemic analysis of the integrative activity of a neuron], Uspekhi fiziologicheskikh nauk [Advances in physiological sciences], V. 5. \# 2, 1974, pp. 5-92.

3. Antsyferova L.I., Psikhologiya lichnosti kak otkrytoi siste$m y$ [Psychology of personality as an open system], Voprosy psikhologiyi [Questions of psychology], \# 5, 1970, P. 168-178.

4. Arkhiv Rossiyskoy akademiyi nauk (ARAN) [Archive of the Russian Academy of Sciences (The RAS Archive)]. Folio 2, List 1 (1971), Folder 7.

5. The RAS Archive, Folio 2, List 6, Folder 957.

6. The RAS Archive, Folio 1844, List 1, Folder 111.

7. The RAS Archive, Folio 2097, List 1, Folder 2

8. The RAS Archive, Folio 2097, List 1, Folder 3.

9. The RAS Archive, Folio 2097, List 1, Folder 5.

10. The RAS Archive, Folio 2097, List 1, Folder 6.

11. The RAS Archive, Folio 2097, List 1, Folder 9.

12. Barabanshchikov V.A., Zhuravlev A.L., Kol'tsova V.A., Sistemnoye issledovaniye psikhicheskogo $v$ rabotakh B.F. Lomova [Systemic study of the mental in the works of B.F. Lomov], Psikhologicheskiy zhurnal [Psychological Journal], 2007, Vol. 28, \# 3, pp. 5-13.

13. Belopolsky V.I., Zhuravlev A.L., Kostrigin A.A., Istoriya organizatsiyi i nachalo deyatel'nosti Instituta psikhologiyi AN SSSR v dokumentakh $i$ vospominaniyakh sovremennikov [The history of the organization and emergence of the Institute of Psychology of the U.S.S.R. Academy of Sciences in the documents and memoirs of contemporaries]. Psikhologicheskiy zhurnal [Psychological Journal], 2020, Vol. 41, \# 5, pp. 97-107.

14. Bernshtein N.A., Fiziologiya dvizheniya i aktivnost' [Physiology of motion and activity] / Ed.: O.G. Gazenko. Nauka Publishers, Moscow, 1990.

15. Blauberg I.V., Yudin Ye.G. Stanovleniye i sushchnost' sistemnogo podkhoda [Formation and essence of the systemic approach]. Nauka Publishers, Moscow, 1973.

16. Vygotskiy L.S. Izbranniye psikhologicheskiye issledovaniya [Selected Psychological Studies]. Publishing House of the Academy of Pedagogical Sciences of the RSFSR, Moscow, 1956.

17. Vydayushchiyesya uchoniye Instituta psikhologiyi RAN: Biograficheskiye ocherki [Outstanding Scientists of the Institute of Psychology of the Russian Academy of Sciences: Biographical Sketches]. Comp.: A.L. Zhuravlev, V.I. Belopol'skiy. Institut Psikhologiyi RAN [RAS Institute of Psychology Publishing house], Moscow, 2020.

18. Zhuravlev A.L., Kol'tsova V.A., Boris Fyodorovich Lomov - uchoniy, rukovoditel', chelovek ( $k$ 85-letiyu so dnya rozhdeniya). Razvitiye psikhologiyi v sisteme kompleksnogo chelovekoznaniya: Materialy Vserossiyskoy nauchnoy konferentsiyi, posvyashchennoy 40-letiyu Instituta psikhologiyi i 85-letiyu yego osnovatelya B.F. Lomova: $v 2$ chastyakh. Chast' 1 [Boris Fedorovich Lomov, scientist, leader, person (to the 85th anniversary of his birth). Development of psychology in the system of comprehensive human knowledge: Materials of the All-Russian Scientific conference dedicated to the 40th anniversary of the Institute of Psychology and the 85th anniversary of its founder B.F. Lomov: In 2 parts. Part 1]. Ed.-in-chief: A.L. Zhuravlev, V.A. Kol'tsova. Institut psikhologiyi RAN Publishers, Moscow, 2012, pp. 11-15.

19. Zuyev K.B., Teoreticheskiye i filosofskiye osobennosti nauchnoy deyatel'nosti Instituta psikhologiyi AN S.S.S.R. na etape stanovleniya (po arkhivnym materialam) [Theoretical and philosophical features of the scientific activity of the Institute of Psychology of the U.S.S.R. Academy of Sciences at the stage of formation (based on archival materials)]. Kontsept: filosofiya, religiya, kul'tura [Concept: philosophy, religion, culture], 2018, \# 2 (6), pp. 44-53.

20. Ivanova T.A., Istoriya i sovremennoye sostoyaniye sistemnogo podkhoda $v$ otechestvennoy psikhologiyi [History and current state of the systemic approach in Russian psychology]: Dis. ... kand. psikhol. nauk [Thesis for a Candidate Degree in Psychological Sciences], Perm', 2005.

21. Kagan M.S., Chelovecheskaya deyatel'nost' (Opyt sistemnogo analiza) [Human Activity (Experience in Systems Analysis)]. Politizdat Publishers, Moscow, 1974.

22. Kol'tsova V.A., Nauchnaya diskussiya kak predmet sistemnogo issledovaniya [Scientific discussion as a subject of systemic research], Sovremennaya psikhologiya: sostoyaniye i perspektivy. Tezisy dokladov na yubileinoy nauchnoy 
konferentsiyi Instituta psikhologiyi RAN, 28-29 yanvarya 2002 g. $V 2$ t. [Modern psychology: state and prospects. Abstracts of reports at the jubilee academic conference of the Institute of Psychology of the Russian Academy of Sciences, January 28-29], Vol 1. Ed.-in-chief: A.V. Brushlinsky, A.L. Zhuravlev. Institut psikhologiyi $R A N$ Publishing house, Moscow, 2002, pp. 45-48.

23. Kol'tsova V.A., Sistemniy podkhod i razrabotka problem istoriyi otechestvennoy psikhologicheskoy nauki [A Systems Approach and the Development of Problems in the History of Domestic Psychological Science]. Psikhologicheskiy zhurnal, 2002, V. 23, \# 2, p. 14-16.

24. Kol'tsova V.A., Zhuravlev A.L., B.F. Lomov - novator i pervoprokhodets $v$ psikhologicheskoy nauke ( $k$ 90-letiyu so dnya rozhdeniya) [B.F. Lomov as an innovator and pioneer in psychological science (on the 90th anniversary of his birth)]. Psikhologicheskiy zhurnal, 2017, V. 38, \# 6, pp. 5-16.

25. Kuz'min V.P., Printsip sistemnosti v teoriyi $i$ metodologiyi K. Marksa [The principle of systemicity in Marx's theory and methodology]. Politizdat Publishers, Moscow, 1976.

26. Leontiev A.N., Problema deyatel'nosti v psikhologiyi [The problem of activity in psychology]. Voprosy filosofiyi, 1972, \# 9, pp. 95-108.

27. Lomov B.F., O sistemnom podkhode v inzhenernoy psikhologiyi [On the systemic approach in engineering psychology]. Studia Psychologica., 1975, Vol. 17, \# 2, pp. 86-93.

28. Lomov B.F., O sistemnom podkhode v inzhenernoy psikhologiyi [On the systemic approach in engineering psychology]. Voprosy filosofii, 1975, \# 2, pp. 31-45.

29. Lomov B.F., O sistemnom podkhode v inzhenernoy psikhologiyi [On the systemic approach in engineering psychology]. Psikhologiya chelovecheskogo ucheniya. Izbrannyye doklady 2-oy prazhskoy konferentsiyi 16-20 iyula $1973 \mathrm{~g}$. [Psychology of human learning. Selected papers from the 2nd Prague conference, July 16-20, 1973]. Bratislava: Psychodiagnostika, 1976, pp. 221-232.

30. Lomov B.F., Metodologicheskiye i teoreticheskiye problemy psikhologiyi [Methodological and theoretical problems of psychology]. Nauka Publishers, Moscow, 1984.
31. Lomov B.F., Vystupleniye na torzhestvennom sobraniyi, posvyashchennom 15-letiyu obrazovaniya Instituta psikhologiyi RAN [Speech at the solemn meeting marking the 15 th anniversary of the establishment of the Institute of Psychology of the USSR Academy of Sciences]. Psikhologicheskiy zhurnal [Psychological Journal], 1991, V. 12, \# 4, pp. 16-26.

32. Luriya A.R. Mozg cheloveka i psikhicheskiye protsessy. V 2 t.. T. 1. Neiro-psikhologicheskiye issledovaniya [The human brain and mental processes: In 2 volumes. Vol. 1. Neuropsychological research]. Academy of Pedagogical Sciences of the RSFSR Publishing house, Moscow, 1963.

33. Platonov K.K. O sisteme psikhologiyi. Mysl' Publishers, Moscow, 1972.

34. Sadovsky V.N., Osnovy obshchey teoriyi sistem: logikometodologicheskiy analiz [Fundamentals of general systems theory: logical and methodological analysis]. Nauka Publishers, Moscow, 1974.

35. Tyukhtin V.S., Otrazheniye, sistemy, kibernetika: Teoriya otrazheniya $v$ svete kibernetiki i sistemnogo podkhoda [Reflection, systems, cybernetics: reflection theory in the light of cybernetics and systemic approach]. Nauka Publishers, Moscow, 1972.

36. Uyemov A.I., Sistemniy podkhod i obshchaya teoriya sistem [A systemic approach and general systems theory]. Mysl' Publishers, Moscow, 1978.

37. Shorokhova Ye.V., Psikhologicheskiy aspekt problemy lichnosti [The psychological aspect of the problem of personality], Teoreticheskiye problemy psikhologiyi lichnosti [Theoretical problems of personality psychology]. Ed.inchief: Ye.V. Shorokhova. Nauka Publishers, Moscow, 1974, p. 3-33.

38. Yaroshevskiy M.G., Funktsiya diskussiyi v predmetnologicheskom razvitiyi nauki [The Function of Discussion in the Cognitive Development of Science], Rol' diskussiy $v$ razvitiyi yestestvoznaniya [The Role of Discussions in the Development of Natural Science.]. Ed-in-chef: M.G. Yaroshevsky. Nauka Publishers, Moscow, 1986, pp. 8-39. 